\title{
Minimally invasive 2nd stage surgery for preservation of keratinized gingiva around implant: Case reports
}

\author{
Keon-Il Yang, Kyung-Hyun Lee, Jung-Hwa Kim, Sang-Joun Yu* \\ Department of Periodontology, Chosun University School of Dentistry, Gwangju, Korea
}

\begin{abstract}
Implant secondary surgery is an operation that exposes the implant fixture into the oral cavity. Depending on the surgical procedure, keratinized gingiva surrounding the implant may be affected, that may affect long-term prognosis of the implant. The purpose of this case report is to introduce a minimally invasive 2nd stage surgery and to evaluate its clinical features and effect on preservation of keratinized gingiva. Minimally invasive 2nd stage surgery was performed in three patients that had completed first stage implant surgery. The width of keratinized gingiva was measured immediately after surgery and after completion of prosthesis. As a result, the width of keratinized gingiva was preserved, patient's discomfort was reduced, and the operation duration was shortened.
\end{abstract}

Key Words: Dental implants, Gingiva, Minimally invasive surgical procedures

(c) This is an open-access article distributed under the terms of the Creative Commons Attribution Non-Commercial License (http://creativecommons.org/licenses/by-nc/4.0) which permits unrestricted noncommercial use, distribution, and reproduction in any medium, provided the original work is properly cited.

\section{서 론}

임플란트 식립술은 크게 임플란트 고정체(fixture)를 치조 골 내에 식립하는 1차 수술과 임플란트 고정체에 치유지대주 (healing abutment)를 연결하여 구강 내로 노출시키는 2차 수 술로 나눌 수 있다. 그리고, 1차 수술과 2차 수술을 동시에 하는 가 또는 일정한 기간을 두고 순차적으로 하는가에 따라 1단계 수술법과 2단계 수술법으로 나눌 수 있다. 1단계 수술법은 초 기고정이 우수하고, 골결손부가 없어 치조골재생술이 필요하지 않을 경우에 주로 사용된다. 2단계 수술법은 치조골재생술이 동 반되거나, 초기고정이 우수하지 않은 경우에 판막 하방에서 고 정체와 골조직을 보호하기 위하여 시행할 수 있다.

2단계 수술법으로 임플란트를 식립할 경우 판막의 일차폐쇄 가 필수적이다. 이는 점막치은경계의 치관측 변위를 초래하며
[1], 그 결과 추후 임플란트 주변의 각화치은의 폭경에 영향을 미칠 수 있다. 임플란트 주변의 각화치은의 필요성에 대해서는 아직까지 논란의 여지가 있다. 하지만 심미, 보철제작의 용이성, 치은 퇴축에 대한 저항, 치태조절의 용이성 등 임플란트 주변의 각화치은의 존재는 여러가지 장점을 가진다[2].

2단계 수술법에서 임플란트 2차 수술은 성공적으로 골유착된 임플란트 주변의 각화치은의 형태를 결정하는데 중요한 역할을 한다. 근단변위 판막술, 결합조직 이식술, 유리치은 이식술, 유 경판막(pedicle flap) 등 다양한 임플란트 2차 수술법이 임플란 트 주변의 각화치은을 확보하기 위해 소개되었다[3-5]. Hertel 등[6]은 임플란트 2차 수술 방법을 크게 절제형(excisional) 수 술법과 절개형(incisional) 수술법으로 분류하였으며 임플란트 주변의 각화치은 폭이 $4 \mathrm{~mm}$ 이하일 경우 절개형 방법을 통해 임플란트 주변의 각화치은 확보가 가능하다고 하였다.

Received August 24, 2018; Revised September 16, 2018; Accepted September 17, 2018

Corresponding author: Sang-Joun Yu, Department of Periodontology, Chosun University School of Dentistry, 303 Pilmun-daero, Dong-gu, Gwangju 61452, Korea

Tel: +82-62-220-3850, Fax: +82-62-224-4664, E-mail: sjyu78@chosun.ac.kr

Copyright () 2018, Oral Biology Research Institute 
이 논문에서는 Hertel 등[6]이 소개한 절개형 수술법을 변형 하여 봉합 없이 최소한의 절개로 임플란트 2차 수술을 진행한 후, 해당 술식이 가지는 임상적인 특징과 임플란트 주변 각화치 은에 미치는 영향에 관하여 평가하였다.

\section{증례보고}

\section{수술방법}

$1: 100,000$ 에피네프린을 포함한 $2 \%$ 리도카인을 사용하여 국 소마취 시행 후 치조정 절개를 시행하였다. 치조정 절개 길이는 고정체의 둘레길이를 2 로 나눈 값으로, 고정체 직경의 약 1.6 배 에 해당하는 길이로 시행하였다(Fig. 1). 치조정 절개의 위치는 식립된 임플란트 고정체의 정중앙에 최대한 근접하면서 상악의 경우 협측에, 하악의 경우 협설측에 존재하는 부착치은의 폭경 이 최소 $2 \mathrm{~mm}$ 이상 잔존하도록 고려하여 절개를 시행하였다. 치간유두 부위 판막의 손상을 최소로 하기 위하여 자연치와 인 접한 부위에서는 치조정 절개와 인접 자연치 치면 사이의 거리 가 최소 $2 \mathrm{~mm}$ 가 유지되도록 치조정 절개를 시행하였다. 임플 란트와 인접치간 거리가 좁고 치은이 두꺼워 임플란트 고정체 노출이 어려울 경우 점막치은경계를 벗어나지 않도록 부착치은 내에서 수직절개를 부여하였으며 최대길이는 고정체 직경의 길 이 이하로 제한하였다(Fig. 2). 임플란트 고정체를 노출시킨 후 치유지대주를 연결하였으며 봉합은 시행하지 않았다. 부착치은 의 폭경은 치주탐침을 이용하여 밀리미터 단위로 측정하였으며

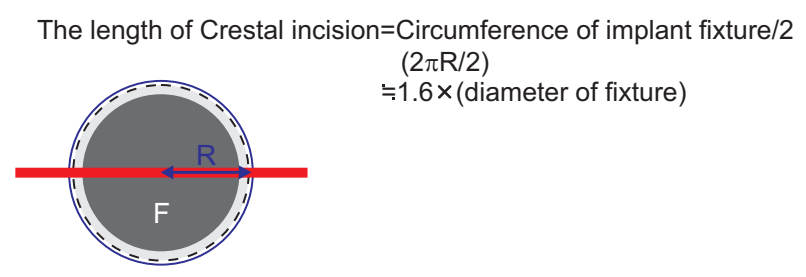

Fig. 1. Formula for minimalized crestal incision length. F, fixture; R, diameter of fixture/2.
2차 수술 직후와 약 3 개월 후 보철이 완료된 시점에 측정하였 다. 상악의 경우 순협측 중앙에서 측정하였으며 하악의 경우 순 협측 및 설측 중앙부위에서 각각 측정하였다.

\section{증례 1}

69세 여성 환자로 \#47치아를 치근파절로 발거하였으며 임플 란트 식립을 주소로 내원하였다. 발치와의 치유상태는 양호하 며 전신질환은 없었다(Fig. $3 \mathrm{~A}$ ). 직경 $5 \mathrm{~mm}$ 의 임플란트를 식립 하였고, 임플란트 식립 후 3개월 후에 임플란트 2차 수술을 진 행하였다. 인접 자연치와의 거리가 충분하고 치은의 두께가 두 껍지 않아 $8 \mathrm{~mm}$ 의 치조정 절개만 시행하였다(Fig. 3B). 임플란 트 고정체 노출 후 덮개 나사를 제거하고 직경 $6.5 \mathrm{~mm}$ 의 치유 지대주를 연결하였다(Fig. 3C). 치유지대주 연결 시 약간의 저항 감과 함께 치은압박으로 인한 치은의 색조변화가 관찰되었으나 임플란트 플랫폼과 치유지대주 사이 연조직의 개제 없이 연결 이 가능하였다. 치유지대주 연결 직후 부착치은의 폭경은 협설 측으로 각각 $3 \mathrm{~mm}$ 로 측정되었으며 3개월 후 보철제작이 완료 된 시점의 부착치은 폭경은 협설측 각각 $3 \mathrm{~mm}$ 로 2 차 수술 직후 와 동일하게 측정되었다(Fig. 3D, E).

\section{증례 2}

47세 남성 환자로 하악 전치부의 결손부위 수복을 주소로 내 원하였다. 만성 치주염으로 인하여 \#32-42까지 치아가 상실되 었고 잔존치조제의 수평 수직적 결손이 관찰되었다. 고혈압과 고지혈증으로 인한 약 복용 중이었으나 전신질환이 잘 조절되 는 상태로 임플란트 식립에 영향을 미치지 않았다. 임플란트 식 립에 앞서 치조골재생술을 시행하였고 직경 $4 \mathrm{~mm}$ 의 임플란트 를 \#32, 42 위치에 각각 식립하였다. 4개월 뒤 임플란트 2차 수 술을 진행하였으며 $6.5 \mathrm{~mm}$ 의 치조정절개를 임플란트 고정체 상부에 각각 시행하였다. 임플란트 위치를 고려한 치조정절개 결과 잔존 부착치은의 정중앙보다 설측에 치조정절개가 위치하 였으나 순설측으로 $2 \mathrm{~mm}$ 이상의 부착치은이 잔존하였다(Fig.
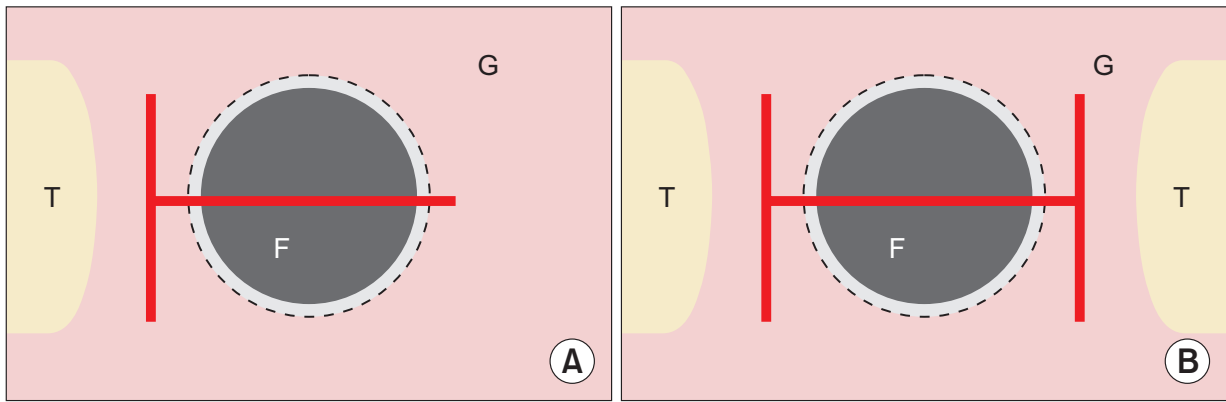

Fig. 2. Modification of minimalized incision design. (A) Two-incision design. (B) Three-incision design. T, tooth; F, fixture; $\mathrm{G}$, gingiva; Red line, incision line. 

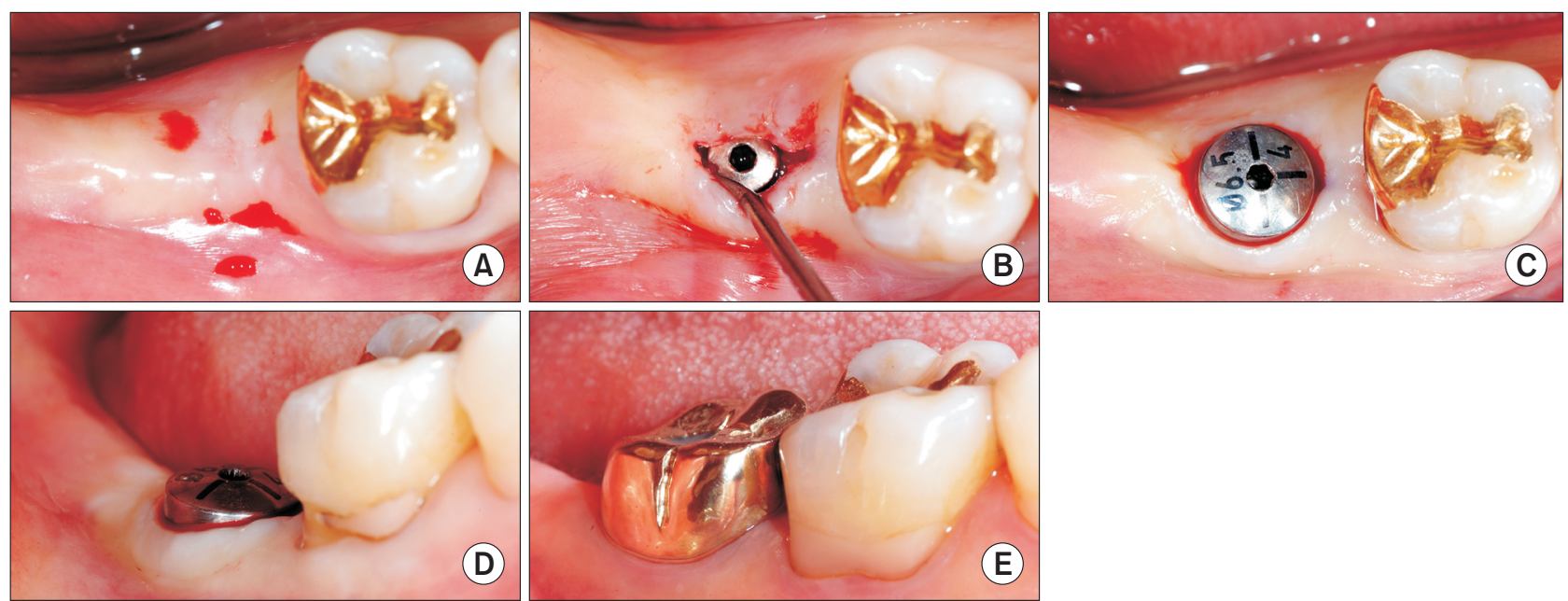

Fig. 3. (A) Occlusal view before implant 2nd stage surgery. (B) Incision design. (C) Occlusal view after healing abutment installation. (D) Buccal view after healing abutment installation. (E) Buccal view after prosthodontic treatment.
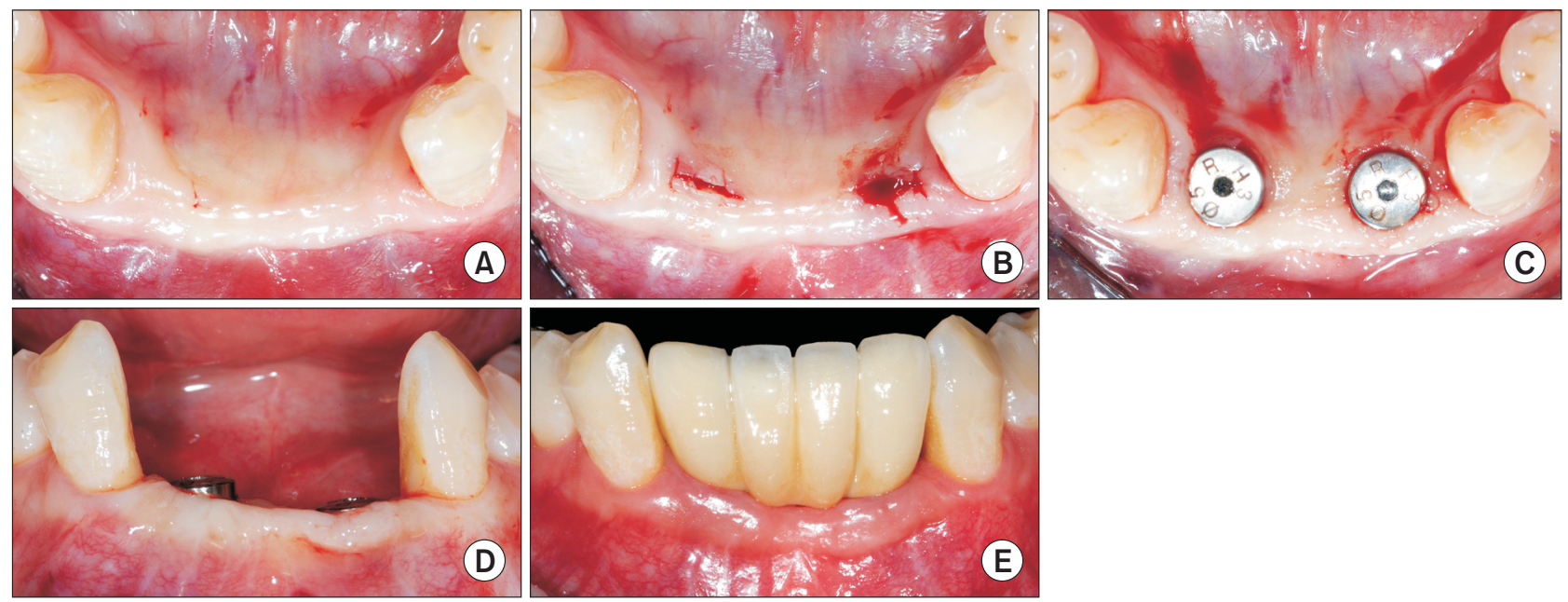

Fig. 4. (A) Occlusal view before implant 2nd stage surgery. (B) Incision design. (C) Occlusal view after healing abutment installation. (D) Buccal view after healing abutment installation. (E) Buccal view after prosthodontic treatment.

$4 \mathrm{~A})$. 고정체의 노출을 쉽게 하기 위해 치아와 인접한 부위에 2 $\mathrm{mm}$ 의 수직절개를 부착치은 내에서 각각 시행하였으며 그 결 과 서로 마주보고 있는 T자 형태의 절개가 형성되었다(Fig. $4 \mathrm{~B}$ ). $5 \mathrm{~mm}$ 직경의 치유지대주를 연결하였으며 봉합은 시행하지 않 았다(Fig. 4 C). 술 후 치유지대주의 순설측 중앙에서 측정한 부 착치은의 폭경은 \#42치아의 경우 $4 \mathrm{~mm} / 2 \mathrm{~mm}$ (순측/설측)였 으며, \#32치아의 경우 $3 \mathrm{~mm} / 2 \mathrm{~mm}$ 로 측정되었으며 3개월 뒤 보철이 완료된 후 재측정 시에도 동일하게 유지되었다(Fig. 4D, E).

\section{증례 3}

43세의 여성 환자로 \#26치아의 임플란트 수복을 주소로 내원 하였다. 치주근관 복합 병소로 인한 해당치아의 발거 병력 있으 며 잔존치조제의 흡수로 인하여 임플란트 식립 전에 치조골재 생술을 시행하였다. 직경 $4.5 \mathrm{~mm}$ 임플란트를 식립하였으며 3 개월 뒤 2차 수술을 진행하였다. 치아 결손부 전후방 길이가 짧 고 임플란트 고정체에 인접하게 자연치가 존재하여 예상된 7 $\mathrm{mm}$ 길이보다 짧은 $6 \mathrm{~mm}$ 의 치조정 절개를 시행하였고 치조정 절개 전후방으로 $4 \mathrm{~mm}$ 의 수직절개를 부착치은 내에 형성하였 다(Fig. 5A, B). 고정체 노출 후 $5 \mathrm{~mm}$ 직경의 치유지대주 연결 

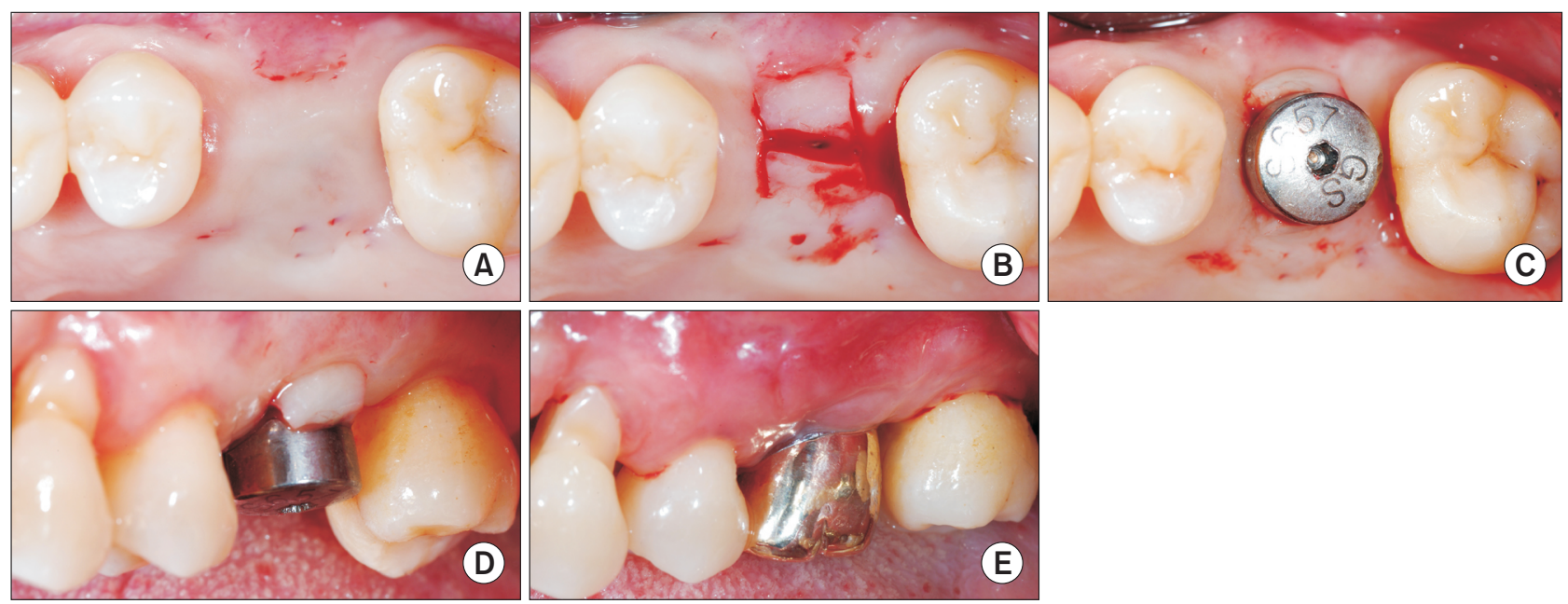

Fig. 5. (A) Occlusal view before implant 2nd stage surgery. (B) Incision design. (C) Occlusal view after healing abutment installation. (D) Buccal view after healing abutment installation. (E) Buccal view after prosthodontic treatment.

하였으며 지대주와 고정체 사이 연조직의 개재를 방지하고자 판막을 최소한으로 거상하고 치유지대주를 연결한 결과, 협측 판막이 치유지대주에 밀려 원래의 위치에 안착되지 못하고 주 변 연조직에 비해 돌출된 상태로 유지되었다(Fig. 5C). 3개월 뒤 보철이 완료된 후 돌출된 판막은 주변의 연조직과 자연스럽게 혼화된 상태로 관찰되었다. 치유지대주 연결 직후 부착치은의 폭은 $3 \mathrm{~mm}$ 로 측정되었으며 3개월 뒤 보철물 연결 후 측정시 협 측 정중앙 부위에서의 부착치은의 폭경은 변화 없이 유지되었 으나 전방에 수직절개 부위는 수술 직후와 비교하여 다소 퇴축 된 형태의 부착치은이 관찰되었다(Fig. 5D, E).

\section{고 찰}

임플란트의 성공을 평가하는 기준으로서 임플란트의 골유착, 임플란트 주변의 방사선학적 골 형태, 기능적인 임플란트 보철 이 주로 평가되어 왔다[7]. 하지만 최근 임플란트의 심미성, 임 플란트 주위염의 예방 등이 주목을 받기 시작하면서 임플란트 주변의 연조직의 형태도 위의 요소들과 마찬가지로 중요하게 고려되고 있다. 임플란트 주변의 각화치은의 필요성은 아직까 지 논란의 여지가 있지만, 치은퇴축이나 치태침착의 예방 등 임 플란트의 유지관리 측면에서 $2 \mathrm{~mm}$ 이상의 각화치은은 긍정적 인 효과를 보이는 것으로 보고되었다[8-10].

단계적 접근법에서 임플란트 2차 수술은 임플란트 식립 및 주변의 경조직에 초점을 맞춘 임플란트 1차 수술 비해 그 중요 성이 간과되는 경향이 있다. 그러나 임플란트 2차 수술은 단순 히 임플란트 고정체를 구강 내로 노출시키는 것뿐만 아니라 임 플란트 주위 연조직의 생물학적 폭경을 형성하며, 효과적인 치
태조절을 위해 임플란트 주위의 각화치은을 확보하고, 임플란 트 주위 연조직의 심미를 위해 적절한 출현 윤곽(emergence profile)을 부여하며, 치간유두를 보존하거나 재건하는데 영향 을 미치기 때문에 1차 수술과 마찬가지로 중요하게 고려되어야 한다. 뿐만 아니라 1차 수술에서 치조골재생술이 동반되었을 경 우 이식골의 보존을 위해서도 최소침습적인 임플란트 2차 수술 은 중요한 의미를 가진다.

다양한 수술법들이 임플란트 주변 연조직의 재건을 위해 사 용되어왔다. 전층판막 거상을 동반한 변위 판막술은 임플란트 주변에 충분한 양의 각화치은을 만들어줄 수 있지만 노출된 부 위의 골에 악영향을 미칠 수 있고 환자에게 불편감을 초래한다. 결합조직 이식술과 유리치은 이식술은 충분한 양의 각화치은을 만들어줄 수 있는 이점을 가진다. 그러나 수여부를 형성함으로 써 환자의 불편감을 초래할 수 있으며 다수의 임플란트에 대한 처치가 필요할 경우 채취 가능한 이식조직의 양이 제한적이라 는 한계를 가지고 있다.

Bernhart 등[11]과 Happe 등[12]은 이러한 부작용을 방지하 고자 열쇠 구멍 형태로 1 개의 절개선만 부여한 최소침습적인 형 태의 2차 수술법을 소개하였다. 이러한 방법은 임플란트 주변의 각화치은을 최대한으로 보존하고 환자의 불편감을 최소화시킬 수 있다는 장점이 있으나 임플란트 고정체의 확인이 어렵고 고 정체에 대한 접근 및 치유지대주 연결 시 연조직 배제를 위하여 특별히 고안된 기구가 필요하다는 단점이 있다.

Hertel 등[6]은 임플란트 2차 수술 방법에 따라 절제형 술식 과 절개형 술식으로 임플란트 2차 수술을 분류하였고 수술부위 에 $4 \mathrm{~mm}$ 이상의 각화치은이 잔존한 경우 절개형 임플란트 2차 수술을 통해 기존의 각화치은을 유지할 수 있다고 보고하였다. 
이 방법은 부착치은 내에서만 치조정 절개 및 수직절개를 부여 하여 임플란트를 노출시키고 치유지대주를 연결하는 방법으로 특별한 기구 없이 쉽게 접근이 가능하며 환자의 불편감을 줄일 수 있다. 하지만 봉합이 필요하며 인접 치조골이 노출될 가능성 이 있다.

이 논문의 증례에서는 Hertel 등[6]이 소개한 절개형 2차 수술 법을 변형하여 봉합 없이 수술을 진행하였으며 수직절개는 각 화치은 내로 제한하되 협측방향으로 제한한 기존의 방법과는 달리 설측으로 연장하였다. 봉합을 하지 않기 위해 임플란트 고 정체 직경을 이용한 계산으로 치조정절개선의 길이를 정확하게 설정하였으며, 협설측으로 연장된 수직절개를 통해 쉽게 고정 체를 확인할 수 있고, 덮개나사의 제거가 용이하였다. 아울러 치 유지대주 연결 시 임플란트 플랫폼과 치유지대주 사이 연조직 이 말려들어가는 것을 방지할 수 있었다.

치유지대주가 연결 시 약간의 저항성과 함께 주변 연조직의 허혈성 색조변화가 관찰되었고, 전후방으로 수직절개를 준 경 우 판막의 일부가 치유지대주에 밀려 치관측으로 돌출되는 등 문제점도 관찰되었으나 3개월 뒤 보철이 연결된 시점에서 관찰 시 특이할 만한 부작용은 관찰되지 않았다. 측정 단위가 밀리미 터이기 때문에 정확한 측정은 어려웠으나 각화치은의 폭경도 수술 직후와 비교하여 동일하게 유지되었다.

최소 침습적 2차 수술을 위해서는 최소 $4 \mathrm{~mm}$ 의 각화치은이 필요하며, 부족할 경우에는 유리치은 또는 결합조직 이식술이 요구된다. 그러나 $4 \mathrm{~mm}$ 의 각화치은만 확보하면 되기 때문에 필 요한 이식편의 양을 최소화할 수 있다. 치조정 절개가 임플란트 고정체의 중심에서 벗어날 경우도 있었으나 임플란트 식립위치 가 이상적인 위치에서 크게 벗어나지 않는 경우 대개 잔존부착 치은의 중앙과 임플란트 고정체의 중앙선이 일치하거나 근접하 였다. 서지컬 스텐트를 사용하여 임플란트를 식립할 경우, 이러 한 오차는 크게 줄일 수 있을 것으로 예상되며 1차 수술 때 사용 한 서지컬 스텐트를 2차 수술 때 재사용함으로써 보다 쉽고 정 확하게 점막 하방의 임플란트의 위치확인이 가능할 것으로 생 각된다.

결론적으로 이 증례들에서 사용한 최소침습적인 임플란트 2 차 수술은 기존에 존재하던 각화치은을 보철이 연결된 후에도 손실 없이 유지할 수 있었고 판막 거상을 최소화함으로써 점막 하방의 치조골에 미치는 영향을 최소화할 수 있었다. 또한 봉합 을 시행하지 않음으로써 환자의 불편감을 최소화하고 수술시간 을 줄일 수 있는 장점이 있다.

\section{ACKNOWLEDGEMENTS}

This study was supported by research fund from Chosun
University Dental Hospital, 2018.

\section{CONFLICTS OF INTEREST}

The authors declare that they have no competing interests.

\section{ORCID}

\author{
Keon-Il Yang \\ https://orcid.org/0000-0001-8789-7743 \\ Kyung-Hyun Lee \\ https://orcid.org/0000-0001-7714-6743 \\ Joong-Hwa Kim \\ https://orcid.org/0000-0002-5310-7667 \\ Sang-Joun Yu \\ https://orcid.org/0000-0001-8818-549X
}

\section{REFERENCES}

1. Belser UC, Buser D, Hess D, Schmid B, Bernard JP, Lang NP. Aesthetic implant restorations in partially edentulous patients-a critical appraisal. Periodontol 2000 1998;17: 132-150. doi: 10.1111/j.1600-0757.1998.tb00131.x.

2. Alpert A. A rationale for attached gingiva at the softtissue/implant interface: esthetic and functional dictates. Compendium 1994;15:356, 358, 360-362 passim.

3. Khoury F, Happe A. Soft tissue management in oral implantology: a review of surgical techniques for shaping an esthetic and functional peri-implant soft tissue structure. Quintessence Int 2000;31:483-499.

4. Price RB, Price DE. Esthetic restoration of a single-tooth dental implant using a subepithelial connective tissue graft: a case report with 3-year follow-up. Int J Periodontics Restorative Dent 1999;19:92-101. doi: 10.11607/prd.00. 0303 .

5. Salama H, Salama M, Garber D, Adar P. Developing optimal peri-implant papillae within the esthetic zone: guided soft tissue augmentation. J Esthet Dent 1995;7:125-129. doi: 10.1111/j.1708-8240.1995.tb00729.x.

6. Hertel RC, Blijdorp PA, Kalk W, Baker DL. Stage 2 surgical techniques in endosseous implantation. Int J Oral Maxillofac Implants 1994;9:273-278.

7. Albrektsson T, Zarb G, Worthington P, Eriksson A. The long-term efficacy of currently used dental implants: a review and proposed criteria of success. Int J Oral Maxillofac Implants 1986;1:11-25.

8. Chung DM, Oh TJ, Shotwell JL, Misch CE, Wang HL. 
Significance of keratinized mucosa in maintenance of dental implants with different surfaces. J Periodontol 2006; 77:1410-1420. doi: 10.1902/jop.2006.050393.

9. Crespi R, Capparè P, Gherlone E. A 4-year evaluation of the peri-implant parameters of immediately loaded implants placed in fresh extraction sockets. J Periodontol 2010;81:1629-1634. doi: 10.1902/jop.2010.100115.

10. Schrott AR, Jimenez M, Hwang JW, Fiorellini J, Weber HP. Five-year evaluation of the influence of keratinized mucosa on peri-implant soft-tissue health and stability around implants supporting full-arch mandibular fixed prostheses.
Clin Oral Implants Res 2009;20:1170-1177. doi: 10.1111/j. 1600-0501.2009.01795.x.

11. Bernhart T, Haas R, Mailath G, Watzek G. A minimally invasive second-stage procedure for single-tooth implants. J Prosthet Dent 1998;79:217-219. doi: 10.1016/S0022-3913 (98)70218-5.

12. Happe A, Körner G, Nolte A. The keyhole access expansion technique for flapless implant stage-two surgery: technical note. Int J Periodontics Restorative Dent 2010;30:97-101. doi: $10.11607 /$ prd.00.0899. 